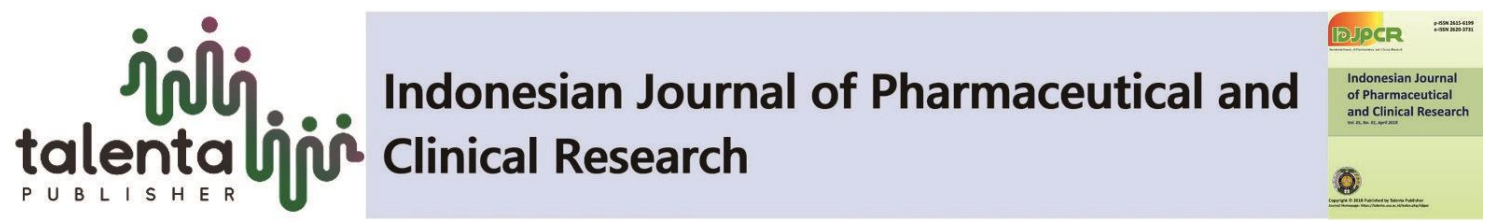

\title{
Preparation and Characterization of Dextrin Obtained from Xanthosoma sagittifolium (L.) Schott Starch with Acid Catalyst and Enzymatic Methods
}

\author{
Sumaiyah*, Selvia Wiliantari, Karsono \\ Department of Pharmaceutical Technology, Faculty of Pharmacy, Universitas Sumatera Utara, Medan \\ 20155
}

\begin{abstract}
Taro has the potential as a substitute material for wheat and rice or as diversification into food and raw materials for pharmaceutical industrial. The aim of this study was to prepare and characterize dextrin from Xanthosoma sagittifolium starch with acid catalyst and enzymatic methods. Dextrin was made by acid catalyst method using $1 \mathrm{~N}$ $\mathrm{HCl}$ and enzymatic method using $\alpha$-amylase enzyme. Dextrin was characterized and tested according to the Indonesian National Standard (SNI) 01-2593-1992. The results showed that the yield from acid catalyst and enzymatic methods were $41.73 \%$ and $67.10 \%$, respectively. The color test showed that dextrin from acid catalyst method was yellowish whereas the enzymatic method gave white dextrin. The characteristic of 80 mesh fineness for dextrin fabricated by acid and enzymatic methods were $94.7 \pm 0.06 \%$ and $93.96 \pm$ $0.02 \%$ respectively. Dextrin obtained from acid catalyst had higher water and ash content than dextrin from enzymatic methods. Dextrin made from enzymatic method had higher solubility in cold water than dextrin from acid catalyst method. Dextrose equivalent for dextrin produced by13.65 \pm 0.36 and $15.31 \pm 0.46$, respectively for acid catalyst and enzymatic methods. Acidity degree of dextrin fabricated from acid catalyst and enzymatic methods were $2.86 \pm 0.23$ and $4.39 \pm 0.4$. The research shows that the characterization of dextrin by acid catalyst and enzymatic methods meet the quality requirements of Indonesian National Standard (SNI) 01-2593-1992.
\end{abstract}

Key words: Taro, dextrin, acid catalyst method, enzymatic method

\begin{abstract}
Abstrak. Talas memiliki potensi sebagai bahan pengganti gandum dan beras atau sebagai diversifikasi ke dalam makanan dan bahan baku untuk industri farmasi. Tujuan dari penelitian ini adalah untuk membuat dan mengkarakterisasi dekstrin dalam pati Xanthosoma sagittifolium dengan katalis asam dan metode enzimatik. Dextrin dibuat dengan metode katalis asam menggunakan $\mathrm{HCl} 1 \mathrm{~N}$ dan metode enzimatik menggunakan enzim a-amilase. Dekstrin dikarakterisasi dan diuji menurut Standar Nasional Indonesia (SNI) 01-2593-1992. Hasil penelitian menunjukkan bahwa hasil dari katalis asam dan metode enzimatik adalah 41,73\% dan 67,10\%,. Uji warna menunjukkan bahwa dekstrin dari metode katalis asam berwarna kekuning-kuningan sedangkan metode enzimatik memberikan dekstrin berwarna putih. Karakteristik kehalusan mesh 80 untuk dekstrin yang dibuat dengan metode asam dan enzimatik masing-masing adalah 94,7\% \pm 0,06 dan $93,96 \% \pm 0,02$. Dekstrin yang diperoleh dari katalis asam memiliki kadar air dan abu yang lebih tinggi daripada dekstrin dari metode enzimatik. Dekstrin yang terbuat dari metode
\end{abstract}

*Corresponding author at: Faculty of Pharmacy, Universitas Sumatera Utara, Medan, Indonesia

E-mail address: sumaiyah@usu.ac.id 
enzimatik memiliki kelarutan yang lebih tinggi dalam air dingin daripada dekstrin yang diperoleh dari metode katalis asam. Kesetaraan dekstrosa untuk dekstrin yang dihasilkan adalah 13,65 $\pm 0,36$ dan 15,31 $\pm 0,46$ untuk katalis asam dan metode enzimatik. Tingkat keasaman dekstrin yang dibuat dari katalis asam dan metode enzimatik adalah 2,86 $\pm 0,23$ dan 4,39 $\pm 0,4$. Penelitian menunjukkan bahwa karakterisasi dekstrin oleh katalis asam dan metode enzimatik memenuhi persyaratan kualitas untuk Standar Nasional Indonesia (SNI) 01-2593-1992.

Kata kunci: Talas, dekstrin, metode katalis asam, metode enzimatik

Received 4 September 2018 | Revised 13 October 2018 | Accepted 26 November 2018

\section{Introduction}

Indonesia is a tropical country with an abundant of natural resources especially in the local tubers plants [1]. Taro tuber is rich of gum (mucilage) that is utilized as binder and emulsifier. It has small granules that are useful as fillers for polyethylene film which is biologically degradable [2].

Unmodified starch (native starch) has shortcomings in which it needs a long cooking time (high energy required), paste formed is hard and not clear. The properties are being too sticky, nonresistance to acid treatment, low viscosity, solubility and swelling. Those cause native starch to have limited usage in industry. Therefore, technology was developed to modify starch with more stable viscosity at either high or low temperature, gel formed is clearer with softer texture, low stretch strength, high solubility and swelling, granules in starch are easily cracked, and gelatinization is at shorter time and lower temperature [3].

One of modified starch is dextrin. It can be made in two ways, such as dry (filtration) and wet methods. Dry method (filtration) causes color change in starch during the process. Therefore, the dextrin produced has darker color. Hence dry method was used to produce dextrin with the addition of acid of enzymes. Dextrin made with acid catalyst has advantages as the process is easy, material is easy to get and cheap [4]. Whereas dextrin made with enzyme can be done in a non-extreme process (medium temperature and $\mathrm{pH}$ closes to normal), with a higher conversion rate and a more specific reaction [2]. Dextrin is polydextrose in pharmaceutical fields that work as diluents for pills and capsules, binder, sugar coating material as plasticizer, adhesive and thickening agent for suspension [5].

Based on the description above, the research was conducted to compare dextrin produced from acid catalysts and enzymatic methods from taro tubers to increase their economic value and utilities. Next, dextrin produced was characterized based on Indonesian National Standard [6]. 


\section{Materials and Methods}

Sample was collected using purposive sampling. The sample was taken without comparing the same sample from different area. Sample used was taro tubers (Xanthosoma sagittifolium (L.) Schott), from Tanah Karo, Brastagi, North Sumatra.

\subsection{Equipments}

The equipments used were glasswares, autoclave (Wisd Laboratory Analystical), blender (Miyako), buret (Oberol), evaporating dish, freezer (LG), hot plate stirrer (Thermo Scientific Cimarex), filter paper, melting point (Stuart), orbital shaker (Major Science), oven (Dynamica), water heater, reaction tube clamp, $\mathrm{pH}$ meter (Eco Tester), 80 mesh sieve, spatula, spot plate, furnace (Stuart), thermometer and digital scale (Boeco Germany).

\subsection{Materials}

The materials used were taro (Xanthosoma sagittifolium (L.) Schott), distilled water, $\alpha$-amylase enzyme (Sigma All-rich), ethanol absolute p.a, Fehling A solution (Fluka Analytical SigmaAldrich), Fehling B solution (Fluka Analytical Sigma-Aldrich), $1 \mathrm{~N} \mathrm{HCl,} 0.1 \mathrm{~N}$ iodine, phenolphthalein indicator, lugol solution, $1 \mathrm{~N} \mathrm{Na}_{2} \mathrm{CO}_{3}$ and $0.1 \mathrm{~N} \mathrm{NaOH}$.

\subsection{Starch Production}

Eight kilograms of taro tubers were cleaned with clean water. Next, taro was cut transversely with the size of $\pm 1 \mathrm{~cm}$ then they were put into blender with a ratio of $5 \mathrm{~L} / \mathrm{kg}$. Sliced taro was blended roughly and was filtered and squeezed. Residue was separated from starch suspension. Then distilled water was added to dregs then squeezed and filtered. The treatment was repeated until clear supernatant was obtained. Starch suspension was left for \pm 24 hours in a container until starch was precipitated. After 24 hours, the cloudy solution was removed and $2 \mathrm{~L} / \mathrm{kg}$ distilled water was added. Then it is left for another \pm 24 hours again. Next, clear liquid at the upper layer was removed and starch precipitation was dried in room temperature. Dried starch was obtained and softened with a blender and sieved with 80 mesh sieve. Qualitative test for starch was conducted with lugol solution [7].

\subsection{Dextrin Preparation}

\subsubsection{Acid Catalyst Method}

Distilled water was added to 300 gram of taro tubers starch until it reached the volume of $1.5 \mathrm{~L}$ to make a $20 \%$ starch suspension. Then $150 \mathrm{ml}$ of acid catalyst $(1 \mathrm{~N} \mathrm{HCl})$ was added and stirred until the mixture was homogenized. Starch suspension was heated in an autoclave for 10 minutes at $110^{\circ} \mathrm{C}$. Hydrolysis reaction was stopped by adding in $217 \mathrm{ml}$ of $1 \mathrm{~N} \mathrm{Na}_{2} \mathrm{CO}_{3}$ until pH 7 was reached. It was then left to cool at room temperature. Next, $300 \mathrm{ml}$ of ethanol absolute p.a (1:1) was added and stirred. Dextrin was kept in freezer for \pm 12 hours to form 2 layers. After 
that it was filtered and the precipitate was collected and dried in oven at $80^{\circ} \mathrm{C}$ for 3 hours. Rough dextrin was produced and it was powdered using a blender and sieved using 80 mesh sieve. Qualitative analysis with lugol solution was conducted. The final product obtained was dextrin powder.

\subsubsection{Enzymatic Method}

Distilled water was added to 50 gram of starch until it reached the volume of $250 \mathrm{ml}$ to make a $20 \%$ starch suspension. Next, the mixture $\mathrm{pH}$ was checked $(\mathrm{pH}=6.8)$. Starch suspension was heated on a hot plate stirrer at $95^{\circ} \mathrm{C}$ and stirred until clear gel (gelatinous) was formed. Next, the temperature was decreased to $40^{\circ} \mathrm{C}$ and $0.025 \mathrm{~g} / 50 \mathrm{~g}$ starch of $\alpha$-amylase enzyme was added (liquefaction). Hydrolysis with continuous stirring was conducted for 24 hours with qualitative analysis using lugol solution for every 3 hours. Enzyme was broken down by allowing dextrin to boil and it is dried in oven at $80^{\circ} \mathrm{C}$ for 7 hours. Then dextrin was powdered in a blender and sieved with 80 mesh sieve. The final product obtained was dextrin powder [7].

\subsection{Dextrin Characteristic Test}

Dextrin characteristic tests included color, qualitative test with lugol solution, fineness of 80 mesh, water and ash content, solubility in cold water, dextrose equivalent (DE) value, melting point and the degree of acidity [6].

\section{Results and Discussion}

\subsection{Yield}

Before dextrin was fabricated, the concentration of taro tubers starch was formulated using the calculation as follow:

Table 1. Preparation of dextrin with acid catalyst method

\begin{tabular}{|c|c|c|c|c|}
\hline Variable & F1 & F2 & F3 & F4 \\
\hline $\begin{array}{l}\text { Starch concentration } \\
(\%)\end{array}$ & 20 & 20 & 20 & 20 \\
\hline $1 \mathrm{~N} \mathrm{HCl}(\mathrm{ml})$ & 15 & 15 & 10 & 10 \\
\hline Temperature $\left({ }^{\circ} \mathrm{C}\right)$ & 110 & 110 & 110 & 110 \\
\hline Time (min) & 10 & 10 & 10 & 10 \\
\hline $1 \mathrm{~N} \mathrm{Na}_{2} \mathrm{CO}_{3}(\mathrm{ml})$ & 28.7 & 25.5 & 14.5 & 18.3 \\
\hline Ethanol (ml) & - & 100 & 100 & 100 \\
\hline Dryer & Oven & Hot plate & Oven & Hot plate \\
\hline Result & $\begin{array}{l}\text { Sticky } \\
\text { dextrin }\end{array}$ & $\begin{array}{c}\text { Wet } \\
\text { dextrin }\end{array}$ & $\begin{array}{c}\text { Yellowish dextrin } \\
\text { powder }\end{array}$ & $\begin{array}{c}\text { Brown dextrin } \\
\text { powder }\end{array}$ \\
\hline
\end{tabular}

Base on the results obtained, F3 method was the best preparation with $1 \mathrm{~N} \mathrm{HCl}$ because dextrin obtained was in powder form with yellowish color and the yield of dextrin was $41.73 \%$. 
Table 2. Preparation of dextrin with enzymatic method

\begin{tabular}{|c|c|c|c|}
\hline Variable & F1 & F2 & F3 \\
\hline Starch concentration $(\%)$ & 30 & 20 & 15 \\
\hline Temperature $\left({ }^{\circ} \mathrm{C}\right)$ & 95 & 95 & 95 \\
\hline$\alpha$-amilase enzyme (g) & 0.03 & 0.01 & 0.0075 \\
\hline Result & No dextrin formed & White dextrin powder & White dextrin powder \\
\hline Dextrin $(g)$ & - & 13.4208 & 5.2450 \\
\hline
\end{tabular}

Base on dextrin fabrication using enzymatic method ( $\alpha$-amylase enzyme), the best method was

F2 with $20 \%$ of starch concentration because the yield of dextrin obtained was $67.10 \%$.

\subsection{Characterization of Dextrin}

Base on the research conducted, dextrin was fabricated using two methods. They were acid catalyst method $(1 \mathrm{~N} \mathrm{HCl})$ and enzymatic method ( $\alpha$-amylase enzyme). The dextrin obtained was characterized based on the Indonesian National Standard number 01-2593-1992. The result can be seen in Table 3,

Table 3. Characterization of dextrin

\begin{tabular}{|c|c|c|c|c|}
\hline \multirow[b]{2}{*}{ No. } & \multirow[b]{2}{*}{ Quality Variable } & \multirow[b]{2}{*}{ SNI 01-2593-1992 } & \multicolumn{2}{|c|}{ Taro Dextrin } \\
\hline & & & $\begin{array}{c}\text { Acid } \\
\text { Catalyst (1N } \\
\text { HCl) }\end{array}$ & $\begin{array}{l}\text { Enzymatic } \\
(\alpha \text {-amilase })\end{array}$ \\
\hline 1. & Color & White to yellowish & Yellowish & White \\
\hline 2. & Color with lugol solution & Brownish purple & $\begin{array}{l}\text { Brownish } \\
\text { purple }\end{array}$ & $\begin{array}{l}\text { Brownish } \\
\text { purple }\end{array}$ \\
\hline 3. & Color with Iodine & - & $\begin{array}{l}\text { Reddish } \\
\text { brown }\end{array}$ & Reddish brown \\
\hline 4. & Fineness of 80 mesh $(\%)$ & Min 90 (pass) & $94.7 \pm 0.06$ & $93.96 \pm 0.02$ \\
\hline 5. & Water content $(\%)$ & Max 11 & $8.79 \pm 0.15$ & $7.62 \pm 0.23$ \\
\hline 6. & Ash content $(\%)$ & Max 0.5 & $0.45 \pm 0.02$ & $0.42 \pm 0.04$ \\
\hline 9. & Solubility in cold water $(\%)$ & Min 97 & $57.47 \pm 0.25$ & $63.09 \pm 0.1$ \\
\hline 8. & Dextrose equivalent & - & $13.65 \pm 0.36$ & $15.31 \pm 0.46$ \\
\hline 9. & Melting point $\left({ }^{\circ} \mathrm{C}\right)$ & - & $185 \pm 0.57$ & $182 \pm 0.57$ \\
\hline 10. & $\begin{array}{l}\text { Acid degree }(0,1 \mathrm{ml} \mathrm{NaOH} \\
\mathrm{N} / 100 \mathrm{~g})\end{array}$ & Max 5 & $2.86 \pm 0.23$ & $4.39 \pm 0.4$ \\
\hline
\end{tabular}

Color test with lugol solution showed brownish purple which indicating reducing sugar whereby the polysaccharide chain was broken down to a simple monomer such as oligosaccharide and glucose. It increase the amount of reduction sugar and gave the purple brownish color when lugol solution is added [4].

The determination of particle size with 80 mesh sieve showed almost the same result to all resulted dextrin. The smaller the modified starch, the better the quality of dextrin because modified starch will be easy to be processed [4]. 
Water content analysis for acid catalyst method gave a higher water content than dextrin made from enzymatic method. A good quality dextrin has a low water content. High water content causes microorganism to grow and reduce the quality. Dextrin with lower water content is easy to be kept and applied [4].

Ash content related to the mineral contained in the raw material, taro. Ash is inorganic matter from the remaining from the combustion of organic matter [8]. The analysis of ash content in dextrin produced from acid catalyst and enzymatic methods had met the requirement of dextrin.

Solubility test in cold water for dextrin made from acid catalyst was lower than dextrin made from enzymatic methods. Starch modification with acid catalyst was happened from the termination of $\alpha-(1,4)$ glycosidic bonds in starch by water with the help of $1 \mathrm{~N} \mathrm{HCl}$ catalyst. While in enzymatic method ( $\alpha$-amylase enzyme) there is a random termination of $\alpha$ - $(1,4)$ glycosidic bonds or at the middle of polymer chains [2]. The higher the concentration of acid and enzymes used, the faster the hydrolysis process was which meant more sugar was produced [4].

DE value for dextrin fabricated by acid catalyst was lower than dextrin fabricated by enzymatic method ( $\alpha$-amylase enzyme). The differences in DE value were caused by $\alpha$-amylase enzyme as endoenzyme that is able to break $\alpha-(1,4)$ bond randomly or at the bonds between polymer chains. $\alpha$-amylase enzyme had specific work in taro tubers starch hydrolysis resulting simple monomer which increase of reducing sugar. Whereas acid catalyst worked randomly in taro hydrolysis. The factors affecting hydrolysis process are starch and acid concentration, enzymes activity and hydrolysis duration. High DE material generally gets brown, hygroscopic, sweet and soluble in water while material with low DE is used as viscosity control, binder or as material for film coating [9].

Dextrin melting point is $178^{\circ} \mathrm{C}$. The difference in the melting point was due to the variance in the total of dextrose equivalent (reducing sugar) as dextrin fabricated was not a pure excipient to serve pharmaceutical needs [5].

Acidity degree in dextrin fabricated from acid catalyst was lower than dextrin fabricated from enzymatic method. It was due to the dextrin preparation with enzymatic ( $\alpha$-amylase enzyme) method was done on lower $\mathrm{pH}, 6.8$. On the other hand, there was a neutralization by $\mathrm{Na}_{2} \mathrm{CO}_{3}$ in acid catalyst method to get $\mathrm{pH} 7$ which explains the lower acidity degree. $\mathrm{pH}$ specification for dextrin is $2-8$ [5]. Acidity degree tells how high the acid content in the material is. The higher the acid, the lower the $\mathrm{pH}$. Acidity degree is greatly affected by acid neutralization technique used [4]. 


\section{Conclusion}

Dextrin from taro tubers starch (Xanthosoma sagittifolium (L.) Schott) with acid catalyst (1 N $\mathrm{HCl})$ and enzymatic ( $\alpha$-amylase enzyme) methods fulfill the criteria of Indonesian National Standard (SNI) 01-2593-1992. There are differences in characteristic of dextrin produced from taro tubers starch (Xanthosoma sagittifolium (L.) Schott) by acid catalyst and enzymatic methods such as yield, colour, fineness of 80 mesh, water and ash content, solubility in cold water, dextrose equivalent, melting point and acidity degree.

\section{Acknowledgement}

The authors would like to thank the Faculty of Pharmacy University of Sumatera Utara that provided facilities in this research.

\section{REFERENCES}

[1] H. Nurcahya, Cultivation and Processing of Taro for food and medicine.,Pustaka Baru Press, Yogyakarta, p.1. 2014

[2] S. Ridal, "Characterization of Physico-chemistry of Colocasia esculenta and Xanthosoma sp. Starches and Acceptance Test of $\alpha$-amylase to Starch". Theses. Institut Pertanian Bogor, Bogor, p.1, 2, 5, 17, 2003

[3] S. Koswara,, "Technology of Starch Modification", 2009. [Online]. Available: http://ebookpangan.com//teknologi_modifikasi_pati. [Accessed: 19 November 2014]

[4] P.W. Jati, "Effect of Hydrolysis Time and $\mathrm{HCl}$ Concentration on Dextrose Equivalent (DE) Value and Quality Characterization of Modified Starch Of Tapioca Starch With Acid Hydrolysis Method”. Theses. Institut Pertanian Bogor. Bogor. p. 1, 49, 56. 2006

[5] RC. Rowe, P.J. Sheskey, and M.E. Quinn . Handbook of Pharmaceutical Excipients Sixth Edition, Pharmaceutical Press, London, pp 220, 223. 2009

[6] Indonesian National Standard, Dextrin for Food Industry, Badan Standarisasi Nasional, Jakarta. 1992

[7] D. Riana Ningsih, A. Asnani, and A. Fatoni, "Development of dekstrin from sweet patile using amilase enzyme from azospirillum sp. Jg3 and its characteristics" Molekul, vol. 5, no. 1, p. 15, May 2010.

[8] A Triyono, "Efforts to Utilize Colocasia esculenta as The Source of Starch on Developing Dextrin Making Technology" In Proceeding of National Seminar on Science and Technology Solutions to The Independence of The Nation, p.98, 99. 2006.

[9] J. Sun, X. Li, J. Zeng, B. Liu, and G. Li, "Characterization of dextrin prepared by common neutral and thermostable $\alpha$-amylases," Journal of Food Processing and Preservation, Jun. 2010. 